\title{
ANALISIS PEMAKAIAN BAHASA DALAM SURAT DINAS DI BADAN PUBLIK SULAWESI TENGGARA
}

\author{
Firman A.D. ${ }^{\text {a }}$, Zakiyah M. Husba ${ }^{\text {, }}$, Dwi Pratiwi ${ }^{c}$ \\ ${ }^{a}$ Kantor Bahasa Sulawesi Tenggara \\ Jalan Haluoleo, Kompleks Bumi Praja Anduonohu, Kendari, Indonesia \\ ${ }^{\mathbf{b}}$ Kantor Bahasa Sulawesi Tenggara \\ Jalan Haluoleo, Kompleks Bumi Praja Anduonohu, Kendari, Indonesia \\ ${ }^{\mathrm{c}}$ Kantor Bahasa Sulawesi Tenggara \\ Jalan Haluoleo, Kompleks Bumi Praja Anduonohu, Kendari, Indonesia \\ firmanad041@gmail.com
}

\begin{abstract}
Abstrak
Penelitian ini menguraikan penggunaan bahasa surat di badan publik yang ada di Sulawesi Tenggara. Penelitian ini bersifat kualitatif deskriptif. Untuk menganalisis data surat dinas, digunakan analisis kesalahan berbahasa. Dalam mengidentifikasi dan mengklasifikasi data, digunakan teknik baca markah. Kesalahan-kesalahan penggunaan bahasa diidentifikasi menurut jenis, diklasifikasikan menurut tipe-tipe kesalahan, dan yang terakhir adalah dikoreksi menurut kesalahan. Hasil penelitian memperlihatkan bahwa penggunaan bahasa dalam surat dinas di intansi pemerintah daerah di Sulawesi Tenggara masih banyak kekeliruan. Kekeliruan itu dapat dilihat dalam ketidakseragaman penulisan dalam instansi yang sama. Kesalahan penggunaan ejaan banyak ditemukan dalam ketidaktepatan penggunaan huruf kapital. Nama jabatan dan nama pejabat ditulis dengan huruf kapital. Kesalahan juga ditemukan dalam pemakaian huruf tebal yang seharusnya tidak digunakan pada bagian hal surat, penulisan nama pejabat, dan penulisan nama jabatan serta ditambah lagi dengan penggunaan garis bawah. Kesalahan penulisan kata dasar umumnya terjadi pada kata serapan. Penulisan antara imbuhan $\{d i-\}$ dan kata depan $d i$ masih belum dapat dibedakan pemakaiannya. Selain itu, bentuk dan fungsi tanda hubung (-) dan tanda pisah (-) belum dapat dibedakan.Kesalahan lain yang umum terjadi dalam pemakaian tanda baca adalah ketidaktepatan penggunaan tanda titik (.), titik dua (:), tanda koma (,), tanda garis bawah $\left(\_\right)$, tanda kurung $((\ldots))$, dan tanda titik koma (;).
\end{abstract}

Katakunci: surat dinas, badan publik, analisis kesalahan, Sulawesi Tenggara

\section{Analysis of the Use of Language in Official Letters ofGovernment Institutionsin Sulawesi Tenggara}

\begin{abstract}
The purpose of this research described the use of language in official letters of government in Sulawesi Tenggara. This research had a qualitative-descriptive method. In analyzing the data, it used error analysis. Read-marker technique were used to identified dan classified the data. Errors of the language use was classified according to kinds and types, thenalso corrected by its errors. The result of the research showed that the use of language in official letters of governments in Sulawesi Tenggara have a lot of errors. It was shown in the varicosity of letter writing in the same institution. The errors of using spellingwere found in using the capital letter. The titles name and name of officials were generally written in capital letters. The errors also were found in using bold letters that should not be used in the subject of letters, writing name of officials, and writing titles name, and also using underlining. The errors of the root writing were generally found in loanwords. The use of
\end{abstract}


prefix \{di-\} and preposition di still have been able to distinguish. In addition, there were also unable to distinguish the form and function of a hyphen (-) and dash (-). Another common mistake in discharging punctuation isinaccurate the use of the full stop (.), colon (:), comma (,), underlining (_), parenthese (( )), and smicolon (;). Meanwhile, there were still inappropriate writing of loanwords becausethey wrote in foreign (English) spelling but using the structure of words/sentences in Indonesia.

Key words: official letter, government institutions, error analysis, Sulawesi Tenggara

\section{PENDAHULUAN}

Bahasa Indonesia berkedudukan sebagai bahasa nasional dan bahasa negara. Sebagai bahasa nasional, bahasa Indonesia memiliki fungsi sebagai lambang kebanggaan kebangsaan, lambang identitas nasional, alat pemersatu suku bangsa, dan alat penghubung antardaerah dan budaya. Hal tersebut menunjukkan betapa pentingnya bahasa Indonesia bagi kehidupan berbangsa dan bernegara di Indonesia.

Berdasarkan kenyataan, masyarakat Indonesia dalam bertutur masih banyak yang mengabaikan penggunaan bahasa Indonesia yang baik dan benar. Hal itu disebabkan oleh berbagai hal, di antaranya kurangnya pengetahuan masyarakat mengenai bahasa Indonesia yang baik dan benar, ketidakpedulian masyarakat terhadap eksistensi bahasa Indonesia, dan masih adanya sikap-sikap negatif terhadap bahasa Indonesia. Sikap-sikap negatif terhadap bahasa Indonesia dapat dirasakan dengan munculnya beberapa anggapan seperti, bahasa Indonesia tidak memiliki nilai ekonomi, bahasa Indonesia tidak perlu dipelajari karena bahasa sendiri, bahasa Indonesia sudah pasti dimiliki oleh bangsa Indonesia sehingga dinilai biasa-biasa saja dan tidak perlu diutamakan secara berlebihan, bahasa Indonesia lebih mudah daripada bahasa asing sehingga tidak perlu dipelajari dan diajarkan secara serius,dan bahasa Inggris lebih bermutu dan ilmiah daripada bahasa Indonesia.

Bahasa Indonesia adalah bahasa resmi masyarakat Indonesia yang digunakan mulai kalangan masyarakat awam, masyarakat terpelajar, khalayak organisasi, sampai ke kalangan pengelola administrasi. Penggunaan bahasa Indonesia dalam ranah administrasi, baik pemerintah maupun swasta, menjadi suatu kewajiban seperti yang tertera dalam UU RI No. 24 Tahun 2009, Pasal 30, 31, 33, dan 34.

Aktivitas administrasi di instansi/organisasi yang sangat berkaitan dengan pemakaian bahasa adalah korespondensi atau persuratan. Persuratan menjadi jalur utama dari sebuah aktivitas administrasi. Walaupun teknologi komunikasi sudah berkembang dengan pesat, seperti telepon, faksimile, radio, televisi, dan internet, peran surat tidaklah menjadi semakin kecil. Hal tersebut dikarenakan surat memiliki keunggulan tersendiri dibandingkan dengan alat komunikasi yang lain. Keunggulan itu terletak pada sifat surat yang dapat disimpan (tahan lama), dapat menjadi bukti "hitam di atas putih", dan dapat menjadi pedoman kerja. Sebuah organisasi atau instansi memerlukan dokumen tertulis yang dapat menjadi bukti administrasi yang sewaktuwaktu dapat dipergunakan. Jadi, kemajuan teknologi komunikasi sepenuhnya tidak mampu menggantikan fungsi surat.

Untuk mendukung keunggulan surat, bahasa yang digunakan harus efektif. Isi atau maksud surat harus terang dan jelas agartidak menimbulkan kesalahpahaman bagi penerima atau pembaca. Karena pentingnya surat dalam suatu instansi, baik pemerintah maupun swasta, surat harus dikelola dengan baik dan benar sesuai dengan fungsi serta tujuan surat. Pengelolaan surat pada dasarnya merupakan suatu teknis atau cara pengaturan dan 
penyampaian informasi secara logis, terstruktur, dan sistematis. Suatu surat dapat dikatakan baik apabila bahasa yang digunakan adalah bahasa Indonesia yang benar atau baku, sesuai dengan kaidah bahasa Indonesia, khususnya ejaan, bentuk kata, maupun kalimat. Di samping itu, bahasa surat haruslah efektif, wajar, hemat kata, dan cermat.

Kegiatan administrasi semakin kompleks di era saat ini. Hal itu karena berbagai macam peraturan dan norma dalam kehidupan masyarakat telah memengaruhi perkembangan pengelolaan surat. Kesadaran dan perhatian terhadap surat tampaknya sudah disadari oleh instansi yang ingin maju. Oleh karena itu, penyusunan, penggunaan, dan penyampaian surat menjadi bagian yang mendapat perhatian instansi atau organisasi yang menjalankan sistem administrasi modern.

Berbagai cara atau sistem yang dibuat untuk mengelola surat bukan hanya untuk mendukung kegiatan administrasi, melainkan juga untuk pengelolaan persuratan secara efisien. Dari sistem perkantoran yang dikelola secara manual berubah menjadi sistem otomatis yang bergantung pada penggunaan teknologi modern sebagai alat pendukung manajemen. Konseptor surat bukan hanya dituntut untuk menguasai teknologi, melainkan juga dituntut untuk dapat membuat surat dengan cara yang tepat agar isi surat dapat dipahami oleh pembaca/penerima surat.

Bagi mereka yang bekerja di instansi pemerintah, khususnya yang bekerja di bidang administrasi, pembuatan surat salah satu pekerjaan harian. Walaupun sudah menjadi kebiasaan, tidaklah berarti kegiatan itu dapat dengan mudah dikerjakan oleh setiap pegawai. Surat-surat yang dibuat terkadang kurang jelas maksudnya. Salah satu penyebab ketidakjelasan itu pastinya disebabkan oleh kesalahan atau ketidaktepatan penggunaan bahasa. Kesalahan itu dapat terjadi karena pengonsep surat kurang memahami kaidahkaidah kebahasaan atau bisa juga terjadi karena hal-hal lain yang sifatnya manusiawi, misalnya kurang teliti. Bahasa surat tetap harus memperhatikan pedoman kebahasaan, seperti Ejaan Bahasa Indonesia (EBI), tata bahasa Indonesia baku, dan Kamus Besar Bahasa Indonesia (KBBI).

Penelitian mengenai penggunaan bahasa dalam surat dinas telah banyak dilakukan, baik oleh peneliti maupun mahasiswa yang ingin menyelesaikan studi. Beberapa hasil penelitian yang berkaitan dengan surat dinas dipaparkan sebagai berikut.

Penelitian yang dilakukan oleh Bety yang berjudul "Kesalahan Penggunaan Ejaan yang Disempurnakan dalam Surat Dinas Bappeda Provinsi Kalimantan Timur" menyimpulkan bahwa penulisan surat dinas di Dinas Bappeda Kalimantan Timur belum sepenuhnya mengikuti ketentuan kaidah yang berlaku seperti yang ada dalam Pedoman Umum Ejaan Bahasa Indonesia yang Disempurnakan (2009).

Penelitian lain yang berkaitan dengan surat dinas juga pernah dilakukan oleh Nataliasari (2014) dengan judul "Analisis Kesalahan Ejaan pada Surat Dinas di Balai Desa Butuh Krajan, Kecamatan Tengaran, Kabupaten Semarang". Dalam penelitian ini disimpulkan bahwa pemakaian bahasa Indonesia pada surat dinas di Balai Desa Butuh Krajan masih banyak mengalami kesalahan dari segi penulisan huruf dan tanda baca.

Penelitian berikutnya dalam kaitannya dengan surat dinas adalah yang dilakukan oleh Purwandari, Heni Setya, dan Budhi Setiawan (2014) dengan judul "Analisis Kesalahan Berbahasa Indonesia pada Surat Dinas Kantor Kepala Desa Jladri'. Berdasarkan hasil penelitian bahwa bentuk kesalahan berbahasa Indonesia yang ditemukan pada surat dinas Kantor Kepala Desa Jladri di antaranya kesalahan dalam bidang morfologi, sintaksis, diksi, dan ejaan. 
Bentuk kesalahan berbahasa Indonesia yang paling dominan adalah kesalahan dalam bidang ejaan.

Penelitian berikutnya adalah yang dilakukan oleh Angi (2009) dengan judul "Analisis Kesalahan Bahasa Surat pada Kantor Badan Perencanaan Pembangunan Daerah (BAPPEDA) Kabupaten Jeneponto". Dalam penelitian ini dikemukakan bahwa dalam penulisan masih kurang memperhatikan ejaan, kesalahan penggunaan kata-kata singkatan, dan masih banyak kalimat yang kurang tepat susunannya.

Dalam penelitian lain yang berjudul "Ketidakefektifan Kalimat pada Surat Dinas Pemerintah: Studi Kasus Kabupaten Gorontalo" dikemukakan bahwa masih banyak kesalahan dalam surat dinas yang menyebabkan kalimat tidak efektif, seperti adanya kerancuan, pleonasme, ambiguitas, ketidakjelasan subjek, kemubaziran, kesalahan nalar, dan ketidaktepatan bentuk dan makna kata (M.R., 2019).

Beberapa penelitian yang telah disebutkan di atas, hanya terbatas pada satu instansi atau desa. Kesimpulan yang dihasilkan tidak dapat menggeneralisasi permasalahan penggunaan bahasa surat dinas dalam satu daerah atau wilayah. Lain halnya dengan penelitian ini, yang secara komprehensif menggambarkan permasalahan penggunaan bahasa surat dinas dalam satu provinsi dengan mengambil data pada wilayah-wilayah yang dapat merepresentasikan penggunaan bahasa surat dinas di Sulawesi Tenggara.

Berdasarkan pengamatan sekilas bahwa pemakaian bahasa Indonesia ragam tulis pada surat dinas di beberapa instansi pemerintah daerah Sulawesi Tenggara, baik kota maupun kabupaten, masih banyak ditemukan beberapa kesalahan penulisan, baik ejaan, pilihan kata, maupun kalimat. Secara sepintas, bahasa Indonesia memang mudah bagi yang terbiasa berbahasa Indonesia sebagai alat interaksi sehari-hari secara lisan. Namun, dalam bahasa tulis, pengungkapan harus lebih baik daripada bahasa lisan.

Berdasarkan uraian latar belakang, dapat dirumuskan permasalahan penelitian sebagai berikut, "Bagaimanakah penggunaan bahasa surat di badan publik di Sulawesi Tenggara berdasarkan analisis kesalahan berbahasa?"

Tujuan yang ingin dicapai penelitian ini adalah mendeskripsikan penggunaan bahasa surat di badan publik yang ada di Sulawesi Tenggara melalui sisi analisis kesalahan berbahasa. Hasil penelitian ini dapat memberikan manfaat mengenai gambaran penggunaan bahasa Indonesia pada instansi-instansi yang ada di Sulawesi Tenggara, memetakan letak kelemahan dan kekurangan penggunaan bahasa dalam sebuah surat dinas, dan menjadi bahan informasi bagi para pengonsep dan pembuat surat mengenai penggunaan bahasa surat dinas yang benar.

\section{TEORI}

\section{Analisis Kesalahan Berbahasa}

Berkaitan dengan kajian ini, definisi mengenai analisis kesalahan sangat penting untuk diuraikan sebagai dasar untuk menganalisis berbagai data yang ditampilkan. Berbicara mengenai analisis kesalahan dalam berbahasa atau wacana, sebagian orang mengganggapnya tidak menyenangkan karena apa yang dikemukakan adalah data kesalahankesalahan yang mungkin tidak sedap didengar dan dibaca karena salah satu dari sifat sebagian manusia adalah tidak senang kalau dikiritik dan dikatakan salah, baik itu dalam tindakan, karya, tingkah laku, dan berbahasa. Menurut Ruru (1996), jika kita ingin membina bahasa sebagai suatu disiplin yang mempunyai aturan-aturan dan normanorma, tidak ada salahnya kalau kita memberikan suatu uraian tentang kesalahankesalahan dalam berbahasa atau wacana. Setiap ada aturan, peraturan, atau norma dapat dipastikan bahwa akan terjadi 
pelanggaran-pelanggaran, baik disengaja ataupun tidak.

Ruru (1996) mengemukakan bahwa dalam studi kesalahan yang pernah dilakukan oleh beberapa ahli, istilah yang umum digunakan adalah kata mistakes dan errors. Errors adalah ujaran-ujaran yang salah, sistematis, dan konsisten, sedangkan mistakes adalah kesalahan yang diakibatkan oleh lidah keseleo atau pena yang 'terpelesat' yang hanya sekali-kali terjadi. Menurut para ahli, mistake hanya dilakukan oleh penutur asli (native speaker) yang sebenarnya tahu akan aturan-aturan bahasanya sendiri, tetapi kadang-kadang membuat kesalahan yang kemudian dapat diperbaikinya sendiri. Sebaliknya, error umumnya dilakukan oleh orang-orang yang sedang mempelajari suatu bahasa lain, misalnya bahasa Inggris. Untuk kedua istilah tersebut, Tarigan (1990) menggunakan padanan istilah 'kesalahan' untuk 'error' dan 'kekeliruan' untuk 'mistake'.

Berdasarkan definisi tersebut dapat dikemukakan beberapa hal yang bertentangan dengan kenyataan di lapangan (berkaitan dengan data dalam bahasa surat). Kesalahan-kesalahan yang terjadi dalam penulisan bahasa dalam surat dinas, ada yang dapat dikategorikan sebagai mistake. Namun, secara umum kesalahan yang terjadi dapat dikategorikan sebagai error yang kemungkinan pengonsep surat kurang mengetahui dan memahami sistem dalam bahasa Indonesia karena kesalahan tersebut selalu berulang. Sementara itu, kita mengetahui bahwa pengonsep surat tersebut adalah penutur asli (native speaker) dan penutur aktif bahasa Indonesia. Jadi, apakah dapat disimpulkan bahwa para pembuat surat dinas tersebut tergolong orang yang masih mempelajari bahasa Indonesia, atau boleh jadi mereka bukan penutur asli bahasa Indonesia?

Crystal (dalam Ruru, 1996) mendefinisikan analisis kesalahan (error analysis) sebagai suatu teknik untuk mengindentifikasikan, mengklasifikasikan, dan menginterpretasikan secara sistematis kesalahan-kesalahan yang dilakukan seseorang yang sedang belajar bahasa asing, misalnya bahasa Inggris, dengan menggunakan prinsip-prinsip dan prosedurprosedur yang berdasarkan linguistik, terutama psikolinguistik.

Nataliasari (2014) mengemukakan bahwa analisis kesalahan berbahasa adalah kajian dan analisis kesalahan berbahasa yang dibuat oleh siswa atau peserta didik atau pelajar asing atau seseorang atau bahasa kedua. Analisis kesalahan berbahasa merupakan metode kerja penelaahan kesalahan berbahasa yang meliputi pengenalan data kesalahan serta penemuan struktur kesalahan berdasarkan sumbersumber tersebut.

Kesalahan berbahasa yang biasa dibuat oleh penulis surat perlu dikurangi. Untuk mencapainya, dibutuhkan pengetahuan mengenai segala hal yang berkaitan dengan kesalahan berbahasa yang diteliti dengan saksama. Pengkajian aspekaspek kesalahan tersebut yang dimaksud dengan analisis kesalahan. Menurut Tarigan (1990: 66), melalui kegiatan pengkajian kesalahan dapat diungkap berbagai hal kesalahan berbahasa yang dibuat atau dilakukan oleh siswa (dalam penelitian ini dikaitkan dengan pengonsep dan pembuat surat). Hal-hal yang dimaksud antara lain, latar belakang, sebab-musabab, dan ragam kesalahan.

Lebih lanjut, Tarigan (1990: 68) menuliskan analisis kesalahan sebagai suatu prosedur kerja yang biasa digunakan oleh para peneliti dan guru bahasa, yang meliputi pengumpulan sampel, pengidentifikasian kesalahan, penjelasan kesalahan, pengklasifikasian kesalahan, serta pengevaluasian taraf keseriusan kesalahan.

Dalam Kamus Linguistik dijelaskan bahwa analisis kesalahan (error analysis) dalam pengajaran adalah teknik untuk mengukur kemampuan belajar bahasa 
dengan mencatat dan mengklasifikasikan kesalahan-kesalahan yang dibuat oleh seseorang atau kelompok (Kridalaksana, 2008: 12).

Selanjutnya, Hastuti (1985: 5) menjelaskan bahwa analisis kesalahan merupakan sebuah prosedur yang didasarkan pada analisis kesalahan orang yang sedang belajar dengan objek lisan yang jelas. Maksud dari jelas adalah suatu yang telah dijadikan sasaran. Objek yang dipelajari ialah bahasa. Adapun maksud dari mempelajari adalah melatih terus-menerus dengan berbagai perbaikan, merupakan peristiwa umum yang terjadi dalam mempelajari suatu bahasa. Peristiwa itu diikuti penerapan strategi belajar yang berdaya guna dan berhasil guna dengan aksi yang dapat mendukung secara positif. Semua itu merupakan proses yang multidimensial dan multiphase, yang melibatkan lebih banyak analisis kesalahan yang sederhana, baik bahasa lisan maupun tulis.

Tarigan (1990: 69) mengemukakan bahwa tujuan analisis kesalahan, khususnya dalam pengajaran: (1) menentukan urutan pengkajian butir-butir yang diajarkan dalam kelas dan buku teks; (2) menentukan urutan jenjang relatif penekanan, penjelasan, dan latihan berbagai butir bahan yang diajarkan; (3) merencanakan latihan dan pengajaran remedial; dan (4) memilih butir-butir bagi pengujian dan kemahiran siswa.

Berdasarkan penjelasan tersebut, dapat dikemukakan tujuan analisis kesalahan dalam penulisan surat dinas: (1) menentukan urutan prioritas kesalahan yang akan dibenahi dalam melakukan pembinaan/ penyuluhan; (2) merencanakan penyuluhan/ pembinaan untuk peningkatan kompetensi kebahasaan bagi pengonsep surat berdasarkan data yang sudah dianalisis pada masing-masing instansi; dan (3) menjadi bahan dan masukan bagi pemerintah/instansi dalam menyusun aturan mengenai tata naskah dinas.
Untuk itu, analisis kesalahan bertujuan sebagai umpan-balik penulis dan tidak secara langsung untuk menilai kesalahan. Sebelum menulis surat, penulis dapat merencanakannya terlebih dahulu.Yang paling penting dalam menulis surat adalah pengkajian aspek-aspek kebahasaan dan kalimat sesuai dengan pedoman bahasa Indonesiayang sudah ditetapkan.

Dalam aktivitas persuratan, umumnya instansi pemerintah kurang memperhatikan pentingnya penguasaan dan pengetahuan mengenai aturan-aturan kebahasaan yang berlaku dalam penulisan surat-menyurat, sehingga banyak terjadi kesalahan maupun kekurangan.

\section{Bahasa Indonesia dalam Surat Dinas}

Surat menjadi sarana komunikasi yang vital bagi organisasi. Dalam surat, pesan atau ide penulis disampaikan dalam bahasa tulisan dan dikirimkan kepada penerima untuk mendapat tanggapan.

Menurut Soytaningrum (2008: 1) bahwa surat-menyurat merupakan suatu bentuk komunikasi tertulis yang dilakukan antarorganisasi. Mengingat tidak setiap saat komunikasi dapat dilakukan secara langsung, kehadiran surat akan mewakili organisasi dalam berkomunikasi dengan pihak lain. Adanya keterbatasan waktu, tempat, tenaga, dan biaya menjadikan surat dianggap lebih efisien, efektif, praktis, dan ekonomis dalam mewakili organisasi ketika berkomunikasi dengan publiknya.

Jika dibandingkan dengan bahasa lisan, bahasa surat sebagai alat komunikasi tertulis biasanya lebih singkat. Susunan bahasa surat harus memperhatikan dengan cermat penggunaan kalimat, pilihan kata, dan perangkat ejaan, serta konteks. Semua hal tersebut sangat berpengaruh terhadap penyampaian maksud surat. Isi surat harus simpatik, sopan, luwes tapi luas, dan menarik. Penulis semestinya menghindari pemakaian kata yang kurang tepat, yang bermakna ganda, dan terutama yang dapat 
menyinggung perasaan penerima surat (Bratawidjaja, 1988: 42).

Sejalan dengan itu, Arifin (1989: 60) mengemukakan agar pesan yang terdapat di dalam surat komunikatif dan mudah dipahami oleh penerima, surat hendaknya menggunakan bahasa yang benar sesuai dengan kaidah komposisi atau kaidah karang-mengarang. Pembicaraan kaidah komposisi yang bertalian dengan suratmenyurat mencakupi pemilihan kata, pemakaian ejaan yang disempurnakan, penyusunan kalimat, dan penyusunan paragraf.

Sesuai dengan pembahasan tulisan ini, yakni surat dinas, dapat didefinisikan sebagai surat yang berisi masalah kedinasan yang dibuat oleh suatu instansi pemerintah, instansi swasta, dan organisasi. Surat dinas juga sering disebut sebagai surat resmi karena arti kata dinas dan resmi tidak jauh berbeda (Nadia, 2018: 8).

Dengan mengutip peraturan Pedoman Tata Naskah Dinas Instansi yang dikeluarkan oleh Kementerian Pendayagunaan Aparatur Negara dan Reformasi Birokrasi, RI No. 80 Tahun 2012, bahwa bahasa yang digunakan dalam naskah (surat) dinas harus jelas, tepat, dan menguraikan maksud, tujuan, serta isi naskah. Untuk itu, perlu diperhatikan pemakaian kata dan kalimat dalam susunan yang baik dan benar, sesuai dengan kaidah tata bahasa yang berlaku, yaitu Tata Bahasa Baku Bahasa Indonesia dan Kamus Besar Bahasa Indonesia.Ejaan yang digunakan adalah Ejaan Bahasa Indonesia sesuai dengan ketentuan peraturan perundangundangan.

Keraf (dalam Bety, 2009: 57) mengatakan bahwa salah satu fungsi bahasa Indonesia yang baik dan benar salah satunya adalah sebagai alat untuk menjalankan administrasi negara. Fungsi tersebut jelas dalam surat-menyurat resmi, peraturanperaturan, undang-undang, pidato, dan pertemuan resmi. Bahkan, unsur-unsur administrasi negara sendiri harus menggunakan bahasa Indonesia.

Berdasarkan pemaparan tersebut, jelas bahwa surat-menyurat resmi (surat dinas) harus merujuk ke aturan kebahasaan yang berlaku di Indonesia. Dalam kaitannya dengan penggunaan bahasa, ada beberapa hal yang harus diperhatikan dalam menyusun surat adalah paragraf (alinea), kalimat, diksi (pilihan kata), dan ejaan. Setiap unsur tersebut memiliki syarat-syarat dan ketentuan tersendiri harus dipatuhi dan diikuti untuk mencapai sebuah wacana atau tulisan yang baik.

Salah satu unsur yang memiliki peranan penting dalam penulisan bahasa Indonesia dalam surat dinas adalah pejabat atau pimpinan. Menurut Rasyid (2018: 389), jika pejabat pemerintah bersikap positif terhadap bahasa Indonesia dan mereka mampu menebarkan sikap positif tersebut ke masyarakat umum, ada peluang bahasa Indonesia untuk tetap bertahan sebagai identitas dan kebanggaan bangsa. Jika sebaliknya, pejabat pemerintah bersikap negatif, masyarakat tidak memiliki panutan dalam berbahasa dan akan kehilangan jati diri bangsa.

\section{METODE}

Penelitian ini mendeskripsikan kesalahan pemakaian bahasa Indonesia dalam suratsurat dinas yang ada di intansi pemerintah daerah di Sulawesi Tenggara. Dalam pendeskripsian tersebut dilakukan secara kualitatif deskriptif.

Kualitatif deskriptif dalam penelitian ini, juga disebut naturalistik atau alamiah, digunakan dengan pertimbangan karena diadakan dalam latar yang sesungguhnya sehingga objek tidak berubah, baik sebelum maupun sesudah diadakan suatu penelitian (lihat Ratna, 2013). Sesuai dengan dasarnya sebagai penelitian alamiah, dalam penelitian kualitatif, data dianggap sebagai bagian dari suatu keutuhan. Instrumen penelitian adalah 
peneliti itu sendiri, dengan konsekuensi peneliti harus memiliki kemampuan, baik teori maupun metode, sehingga mampu untuk mewawancarai, menganalisis, mencari makna di balik gejala.

Oleh karena itu, dalam penyusunan rancang penelitian ini disusun berdasarkan pada prinsip deskriptif kualitatif, yang mengumpulkan, mengolah, mereduksi, menganalisis, dan menyajikan data secara objektif atau sesuai dengan kenyataan yang ada di lapangan.

Penelitian ini akan memfokuskan pengambilan dan pengumpulan data di beberapa instansi pemerintah yang berada di tiga lkabupaten/kota, yaitu, Kabupaten Kolaka, Kota Baubau, Kota Kendari, ditambah dengan data dari Pemerintah Provinsi Sulawesi Tenggara. Adapun instansi yang dipilih diacak dan data diambil sesuai dengan kebutuhan penelitian.

Ketiga lokasi ini dipilih karena wilayah tersebut merupakan daerah paling ramai dan paling maju di antara kabupaten/kota lain yang ada di Provinsi Sulawesi Tenggara. Posisi mereka sebagai daerah pelabuhan dan daerah transit bagi masyarakat sangat memengaruhi kegiatan pemerintahan, khususnya dari segi pelayanan administrasi.

Pengumpulan data dilakukan dalam rentang Februari-Maret 2017. Dalam pengumpulan data, peneliti mendatangi beberapa instansi mengumpulkan surat dinas yang dibutuhkan dalam bentuk foto dan fotokopi. Surat dinas yang terkumpul berupa surat undangan, surat keterangan, surat tugas, surat pemberitahuan, surat edaran, pengumuman, dan nota dinas. Selain itu, juga dilakukan pengamatan pada saat proses pembuatan sebuah surat untuk mengetahui peran setiap staf dan pimpinan dalam terbitnya sebuah naskah dinas. Data naskah dinas yang dikumpulkan adalah naskah yang dibuat tahun 2016-2017.

Dalam pengumpulan data, total jumlah surat yang terkumpul sebanyak 147 sumber data dari instansi di tiga kabupaten/kota. Berikut dapat dilihat rincian dalam tabel.

Tabel 1

Jumlah Sumber Data

\begin{tabular}{ccc}
\hline No. & Nama Daerah & Jumlah \\
\hline 1. & Pemprov Sultra & 60 \\
\hline 2. & Pemkot Kendari & 17 \\
\hline 3. & Pemkot Baubau & 38 \\
\hline 4. & Pemkab Kolaka & 32 \\
\hline & Total & 147 \\
\hline
\end{tabular}

Dari 147 data tersebut, tidak semuanya dianalisis karena keterbatasan waktu dan tenaga. Data yang dipilih untuk dianalisis adalah data yang dianggap memiliki kesalahan terbanyak. Sementara data yang lain dijadikan sebagai pembanding untuk data yang terpilih.

Untuk melengkapi data yang ada, dilakukan teknik wawancara yang dimaksudkan untuk mengumpulkan informasi yang berkenaan dengan proses lahirnya dan pengesahan surat dinas dalam sebuah instansi. Teknik wawancara akan didukung oleh instrumen berupa daftar tanyaan yang telah disiapkan agar proses wawancara dapat terarah dan terfokus. Jumlah informan yang diwawancarai dalam penelitian sebanyak enam orang. Informan yang terpilih adalah orang-orang yang mengetahui seluk-beluk proses pembuatan sebuah surat dinas, termasuk pengonsep surat.

Studi pustaka digunakan untuk menjaring data tertulis sebanyak-banyaknya melalui berbagai pustaka yang relevan dengan penelitian ini. Sumber pustaka ini dapat berupa berbagai hasil penelitian yang sejalan dengan judul penelitian dan berbagai kebijakan tertulis mengenai tata naskah surat dinas, baik dikeluarkan oleh kementerian maupun oleh instansi daerah.

Data penggunaan bahasa dalam surat dinas akan dideskripsikan secara jelas dan gamblang dalam kaitannya dengan kenyataan yang berlaku mengenai 
penggunaan bahasa dalam surat dinas. Pendeskripsian penggunaan bahasa dapat dilakukan dengan melihat berbagai segi, di antaranya penggunaan bahasa dalam kepala surat, pembuka surat, isi surat, dan analisis penggunaan ejaan dan penggunaan diksi. Berdasarkan dasar teori yang digunakan dalam kajian ini, yaitu analisis kesalahan, berbagai kesalahan penggunaan bahasa yang ditemukan dalam kajian dipaparkan kemudian dikoreksi melalui pemberian contoh.

Secara rinci, adapun teknik yang digunakan dalam mendeskripsikan dan menganalisis data yang ada dilakukan sebagai berikut.

a. Surat dinas yang terkumpul dibaca berulang-ulang.

b. Menandai ejaan dan kata-kata yang dianggap tidak tepat penggunaannya dalam surat-surat dinas tersebut.

c. Ketidaktepatan tersebut diklasifikasikan berdasarkan kategori kesalahan yang dikandungnya.

Kesalahan berbahasa dianalisis dengan tahapan berikut: (a) mengumpulkan data kesalahan; (b) mengidentifikasi kesalahan; (c) mengklasifikasi kesalahan; (d) mengoreksi kesalahan; dan memperbaiki diksi yang kurang tepat.

Dalam menganalisis data digunakan teknik baca markah (lihat Sudaryanto, 2015). Analisis ini mengedepankan kemampuan peneliti melihat langsung pemarkah yang bersangkutan, yang dapat dilakukan dalam berbagai tataran lingual. Dengan melalui pembacaan markah, dapat diidentifikasi data kesalahan dan mencatat kesalahan-kesalahan yang ada dalam surat tersebut. Setelah itu, diambil sampel dari beberapa kesalahan tersebut. Kesalahan-kesalahan ini diidentifikasi menurut jenis kesalahannya. Jenis-jenis kesalahan yang sudah ditemukan selanjutnya diklasifikasikan menurut kesalahan penggunaan ejaan dam ketidaktepatan penggunaan diksi.
Teknik
mengoreksi kesalahan terakhir $\begin{gathered}\text { adalah } \\ \text { yaitu dengan }\end{gathered}$ memperbaiki kesalahan-kesalahan ejaan dan diksi sesuai dengan kaidah-kaidah bahasa Indonesia yang berlaku. Penyajian hasil analisis data dengan metode informal yaitu perumusannya menggunakan kata-kata biasa.

\section{HASIL DAN PEMBAHASAN}

Penelitian ini tidak bermaksud menghakimi surat dinas yang dijadikan sampel, tetapi memberikan gambaran bagaimana sebuah surat semestinya dibuat yang disesuaikan dengan pengunaan kaidah-kaidah kebahasaan, dalam hal ini kaidah-kaidah dalam bahasa Indonesia. Adapun contohcontoh pembenaran yang diberikan dalam pembahasan surat dinas ini adalah sebuah usulan yang nantinya bisa dipertimbangkan untuk dipergunakan.

\section{Analisis Penggunaan Bahasa dalam Surat Dinas}

Berbicara mengenai penggunaan bahasa tentunya terkait dengan penggunaan ejaan, pilihan kata (diksi), dan penggunaan kalimat. Pada bagian ini, ketiga hal tersebut diuraikan satu per satu untuk mendeskripsikan penggunaan bahasa, khususnya bahasa Indonesia, dalam surat dinas di instansi pemerintah daerah di wilayah Sulawesi Tenggara.

Penggunaan Ejaan dalam Surat Dinas

Ejaan merupakan unsur penting dalam penggunaan bahasa. Karena pentingnya unsur ini, di Indonesia penggunaan ejaan diatur dalam sebuah regulasi, yaitu Peraturan Menteri Pendidikan dan Kebudayaan Nomor 50 Tahun 2015 tentang Pedoman Umum Ejaan Bahasa Indonesia. Dalam aturan tersebut, diatur hal-hal yang berkaitan dengan pemakaian huruf, pemakaian tanda baca, penulisan kata, dan penulisan unsur serapan. Penggunaan ejaan dalam surat-surat dinas dapat dianalisis berdasarkan aturan 
tersebut. Berikut ini dikemukakan analisis yang berkaitan dengan ejaan dalam suratsurat dinas tersebut.

\section{Pemakaian Huruf}

Dalam pemakaian huruf, ada beberapa hal yang harus diperhatikan, di antaranya penggunaan huruf kapital, huruf tebal, dan huruf miring. Berdasarkan data, masih banyak ketidaktepatan pemakaian huruf. Oleh karena terbatasnya ruang dan waktu, dalam analisis ini hanya akan dibahas ketidaktepatan yang umum ditemui dalam pemakaian huruf di surat dinas tersebut.

Ketidaktepatan penggunaan huruf kapital banyak ditemui pada penulisan hal surat. Umumnya, penulisan hal surat ditulis dengan menggunakan huruf kapital di setiap awal kata. Seharusnya hal ditulis hanya dengan huruf awal saja yang kapital, kecuali diikuti oleh nama lembaga atau nama orang, bukan huruf kapital di setiap awal kata.

Ketidaktepatan penggunaan huruf kapital berikutnya adalah dalam kaitannya dengan penutup surat. Nama jabatan dan nama pejabat umumnya ditulis dengan huruf kapital semua. Berdasarkan aturan yang ada, seharusnya pemakaian huruf kapital hanya di tiap awal kata atau dipakai sebagai huruf pertama unsur nama orang.

Dalam isi surat dinas, banyak penggunaan huruf kapital yang seharusnya tidak digunakan. Berikut dikemukakan beberapa contoh data.

1) Serangkaian kunjungan kerja STAF AHLI MENTERI - KEMASYARAKATAN DAN HUBUNGAN ANTAR LEMBAGA (SAM KHAL) KEMENTERIAN KELAUTAN DAN PERIKANAN REPUBLIK INDONESIA Bapak DR. Ir. Suseno, MM dan rombongan

2) ... maka kami minta bantuan 1 orang Personil BABINSA Kelurahan Wameo untuk membantu ....

3) Untuk komunikasi lebih lanjut dapat menghubungi kontak person an. Drs. LA ODE NDISE, M.Si (HP. ......)

Berdasarkan ketiga data tersebut, dapat dikemukakan bahwa penggunaan huruf kapital yang tidak sesuai dengan kaidah. Sebenarnya penulis surat ingin mengemukakan bagian penting dari surat, ingin menonjolkan individu/pejabat, atau ada anggapan bahwa kalau menggunakan huruf kapital semua akan langsung dibaca oleh si penerima. Walaupun tanpa menggunakan huruf kapital, tujuan dari surat adalah untuk dibaca oleh penerima.

Dalam kaitannya dengan pemakaian huruf tebal, data 2) masih dapat berterima pemakaiannya karena si pengirim ingin menegaskan inti dari surat yang dikirim. Sementara itu, pada data 3) pemakaian huruf tebal tersebut tidak perlu karena hal tersebut tidak menyangkut inti surat. Jadi, cara penulisannya yang benar adalah penulisan nama tidak semua menggunakan huruf kapital dan tidak menebalkan semua huruf.

Berikut ini dikemukakan contoh kasus yang umum ditemui dalam kaitannya dengan surat dinas berupa undangan yang penulisan waktu kegiatan dibuat dengan model bersusun.

4) ... untuk menghadiri Rapat Paripurna DPRD dimaksud, yang Insya Allah akan dilaksanakan pada

Hari : Selasa

Tanggal : 14 Februari 2016

Pukul : 09.00 Wita.

Tempat : Aula Rapat Paripurna DPRD Kabupaten Kolaka.

Dengan melihat contoh 4) di atas, dapat dikemukakan beberapa kasus dalam kaitannya dengan penulisan huruf kapital. Seharusnya penulisan kata hari, tanggal, pukul, dan tempat menggunakan huruf kecil karena unsur-unsur tersebut masih merupakan sambungan dari kalimat sebelumnya atau dengan kata lain bukan merupakan awal kalimat. Selain itu, penggunaan huruf kapital pada awal kata insya kurang tepat dan sebaiknya ditulis serangkai. Jadi, penulisan yang tepat adalah insyaallah. Adapun kasus-kasus lain dalam contoh tersebut akan dibahas pada bagian yang lain. 
Sebagaimana pemakaian huruf kapital, pemakaian huruf tebal umumnya digunakan pada hal surat, penulisan nama pejabat, dan penulisan nama jabatan. Inilah kebiasaan yang sampai saat ini sulit untuk dihilangkan dalam penulisan surat dinas. Penggunaan huruf kapital dan bukan huruf kapital atau penggunaan huruf tebal dan bukan huruf tebal tidak akan memengaruhi jabatan seseorang atau penanda tangan surat tersebut. Bahkan, ditambah lagi dengan penggunaan garis bawah. Jadi, pemakaian huruf dalam kasus tersebut sangat berlebihan dan seharusnya disesuaikan dengan kaidah yang berlaku dalam ejaan bahasa Indonesia.

Kasus lain yang sangat umum ditemui dalam penulisan penutup surat adalah penulisan jabatan, ruang, dan golongan yang dalam aturan tata naskah dinas tidak diatur sama sekali. Hal tersebut berarti penulisan jabatan, ruang, dan golongan tidak perlu dicantumkan. Tidak dituliskannya jabatan, ruang, dan golongan bukan berarti pejabat penanda tangan surat itu akan berubah status jabatan, ruang, dan golongan. Kemungkinan pencantuman jabatan, ruang, dan golongan hanya sekadar untuk memperlihatkan kepada staf, penerima surat, dan masyarakat mengenai status penanda tangan surat.

\section{Penulisan Kata}

Dalam ejaan, penulisan kata berkaitan dengan penulisan kata dasar, kata berimbuhan, bentuk ulang, gabungan kata, pemenggalan kata, kata depan, partikel, singkatan dan akronim, angka dan bilangan. Berkaitan dengan hal tersebut, berikut ini dikemukakan beberapa kesalahan penulisan kata berdasarkan data yang ada.

Tabel 2

Kesalahan Penulisan Kata Dasar

\begin{tabular}{lll}
\hline No. & \multicolumn{1}{c}{ Penulisan Salah } & Penulisan Benar \\
\hline 1. & asset & aset \\
\hline 2. & praktek & praktik \\
\hline 3. & copy & kopi \\
\hline 4. & examplar & eksemplar \\
\hline
\end{tabular}

\begin{tabular}{lll}
\hline 5. & prinsipil & prinsip \\
\hline 6. & definitip & definitf \\
\hline 7. & lumpsum & lumsum \\
\hline 8. & shalat & salat \\
\hline 9. & pengelolah & pengelola \\
\hline 10. & majelis ta'lim & majelis taklim \\
\hline 11. & test & tes \\
\hline 12. & devile & defile \\
\hline 13. & SMA / SMP sederajad & $\begin{array}{l}\text { SMA/SMP } \\
\text { sederajat }\end{array}$ \\
\hline
\end{tabular}

Berdasarkan data tersebut, dapat dikemukakan bahwa kesalahan penulisan kata dasar umumnya terjadi pada kata serapan. Masalah ini bukan hanya terjadi dalam penulisan surat dinas, melainkan juga terjadi pada ranah-ranah lain, seperti penulisan berita koran, karya tulis ilmiah, dan spanduk-spanduk. Jadi, ada baiknya penyusun dan pengonsep surat dinas mengetahui penulisan bentuk baku dan benar dari sebuah kata atau istilah.

Selain kesalahan dalam penulisan kata dasar, juga ditemukan beberapa kesalahan dalam penulisan kata berimbuhan. Berikut ini dikemukakan beberapa kesalahan dari kasus tersebut.

Tabel 3

Kesalahan Penulisan Kata Berimbuhan

\begin{tabular}{lll}
\hline No. & \multicolumn{1}{c}{$\begin{array}{c}\text { Penulisan Kurang } \\
\text { Tepat }\end{array}$} & \multicolumn{1}{c}{ Penulisan Benar } \\
\hline 1. & di harap & diharap \\
\hline 2. & di seleksi & diseleksi \\
\hline 3. & di tetapkan & ditetapkan \\
\hline 4. & di tindak lanjuti & ditindaklanjuti \\
\hline 5. & menindak lanjuti & menindaklanjuti \\
\hline 6. & mentaati & menaati \\
\hline
\end{tabular}

Berdasarkan data tersebut, dapat dilihat kasus yang umum terjadi adalah mengenai kesalahan dalam penulisan kata berimbuhan dalam bentuk pasif, seperti pada data 1-6. Seharusnya kata yang ada dalam data tersebut ditulis serangkai antara imbuhan ( $d i$-) dengan kata dasar yang mengikutinya karena masih merupakan satu kesatuan. Ada juga unsur $d i$ yang ditulis tidak serangkai jika berposisi sebagai kata 
depan (preposisi). Misalnya, di rumah, di pasar, di mana, dan lain-lain.

Untuk data 4 dan 5, yang seharusnya ditulis serangkai, dapat dijelaskan bahwa jika ada gabungan kata (kata majemuk) yang mendapat awalan sekaligus akhiran, ditulis serangkai sebagai satu kesatuan. Berbeda halnya dengan kasus 6, yaitu pengimbuhan afiks $\{$ me- $\}$ pada kata yang dimulai dengan huruf /t/ maka huruf /t/-nya akan luluh.

Hal lain yang berkaitan dengan penulisan kata adalah penulisan bentuk ulang. Dalam penulisan bentuk ulang masih terjadi beberapa kesalahan. Data berikut ini memperlihatkan beberapa kesalahan yang berkaitan dengan penulisan bentuk ulang.

Tabel 4

Kesalahan Penulisan Bentuk Ulang

\begin{tabular}{cll}
\hline \multicolumn{1}{c}{ No. } & \multicolumn{1}{c}{ Penulisan Salah } & \multicolumn{1}{c}{ Penulisan Benar } \\
\hline 1. & masing - masing & masing-masing \\
\hline 2. & sehari - hari & sehari-hari \\
\hline 3. & nama - nama & nama-nama \\
\hline 4. & selambat lambatnya & selambat-lambatnya \\
\hline
\end{tabular}

Dalam data di atas, diperlihatkan bahwa kesalahan utama dalam penulisan bentuk ulang adalah kesalahan penggunaan tanda hubung. Sebagian besar konseptor surat masih ada yang menganggap bahwa tanda hubung (-) dan tanda pisah (--) adalah dua hal yang sama. Dalam aturan kebahasaan, tanda hubung (-) memiliki fungsi yang berbeda dengan tanda pisah (--). Tanda hubung (-) sudah umum digunakan dalam bentuk ulang, bukan tanda pisah (--).

Kasus lain yang ditemukan adalah berkaitan dengan penulisan gabungan kata. Dalam pedoman ejaan, penulisan gabungan kata ada yang ditulis secara serangkai dan ada yang ditulis secara terpisah. Berikut ini dikemukakan beberapa kasus penulisan gabungan kata dalam beberapa surat dinas.

Tabel 5

Kesalahan Penulisan Gabungan Kata

\begin{tabular}{rrr}
\hline No. & Penulisan Salah & Penulisan Benar \\
\hline 1. & bekerjasama & bekerja sama \\
\hline
\end{tabular}

\begin{tabular}{cll}
\hline 2. & budidaya & budi daya \\
\hline 3. & lalulintas & lalu lintas \\
\hline 4. & walikota & wali kota \\
\hline 5. & bio data & biodata \\
\hline 6. & dipindah bukukan & dipindahbukukan \\
\hline 7. & non Pegawai & nonpegawai negeri \\
& Negeri & \\
\hline 8. & Pertukaran Pemuda & Pertukaran Pemuda \\
& Antar Negara & Antarnegara \\
\hline
\end{tabular}

Berdasarkan data pada tabel di atas, dapat dikemukakan bahwa data 1-4cara penulisan dilakukan secara terpisah. Sementara itu, data $5-8$ penulisannya ditulis secara serangkai karena dianggap gabungan kata yang sudah padu.

Penulisan ejaan yang masih banyak ditulis secara tidak tepat adalah kata depan di. Berikut ini dikemukakan beberapa kesalahan penulisan dalam kasus tersebut.

Tabel 6

Kesalahan Penulisan Kata Depan $d i$

\begin{tabular}{cll}
\hline No. & Penulisan Salah & \multicolumn{1}{c}{ Penulisan Benar } \\
\hline 1. & diatas & di atas \\
\hline 2. & dilapangan & di lapangan \\
\hline 3. & kedepannya & ke depannya \\
\hline 4. & diwilayah & di wilayah \\
\hline 5. & disamping & di samping \\
\hline
\end{tabular}

Kata $d i$ yang berfungsi sebagai kata depan ditulis terpisah dengan kata yang mengikutinya. Berbeda dengan imbuhan $\{d i-$ \}, yang menyatakan pekerjaan pasif, seperti dimuat, ditulis, dan dikirim. Masih ada yang belum dapat membedakan konteks penggunaan $d i$ sebagai kata depan dan $d i$ sebagai imbuhan.

Kasus lain yang ditemukan dalam kaitannya dengan penulisan kata adalah ketidaktepatan dalam penulisan partikel. Ketidaktepatan itu umumnya terjadi dalam penulisan partikel peryang berarti 'demi', 'tiap', atau 'mulai'.

Tabel 7

Kesalahan Penulisan Partikel

\begin{tabular}{rlr}
\hline No. & Penulisan Salah & Penulisan Benar \\
\hline 1. & perorang & per orang \\
\hline
\end{tabular}




\section{2. perkelas}

per kelas

Cara penulisan yang tepat menurut kaidah ejaan adalah partikel per ditulis terpisah dari kata mengikutinya.

Tabel 8

Kesalahan Penulisan Singkatan dan Akronim

\begin{tabular}{clll}
\hline No. & Singkatan/Akronim & \multicolumn{1}{c}{ Kepanjangan } \\
\hline 1. & adm. & administrasi \\
\hline 2. & s/d & sampai dengan \\
\hline
\end{tabular}

Berdasarkan data dalam Tabel 8, dapat dikemukakan bahwa jika sudah menuliskan kepanjangan dari sebuah singkatan, singkatan tidak perlu dituliskan lagi seperti dalam data 1. Sementara itu, dalam data 2, seperti yang diatur dalam kaidah ejaan bahwa penulisan singkatan yang terdiri atas dua huruf masing-masing diikuti oleh tanda titik.

Tabel 9

Kesalahan Penulisan Angka dan Bilangan

\begin{tabular}{lll} 
No. & Penulisan Salah & Penulisan Benar \\
\hline 1. & 2 (Dua) & dua \\
& & \\
\hline 2. & 40 (empat puluh) & empat puluh \\
\hline
\end{tabular}

Dalam data tersebut, terlihat penulisan yang mubazir. Penulisan angka dan bilangan diatur bahwa apabila bilangan dalam teks yang dapat dinyatakan dengan satu atau dua kata ditulis dengan huruf, kecuali jika dipakai secara berurutan seperti dalam perincian. Jadi, penulisan angka tersebut cukup ditulis dengan huruf karena hanya terdiri atas satu dan dua kata.

Pemakaian Tanda Baca

Pada bagian ini akan dibahas mengenai kesalahan yang umum terjadi dalam kaitannya dengan penggunaan tanda baca berdasarkan data yang ada dalam surat dinas di instansi pemerintah daerah Sulawesi Tenggara. Dalam buku Pedoman Umum Ejaan Bahasa Indonesia yang Disempurnakan, tanda baca terdiri atas beberapa macam, yaitu tanda titik (.), tanda koma (,), tanda titik koma (;), tanda hubung (-), tanda pisah (--), tanda tanya (?), tanda seru (!), tanda kurung [ ( ) ], tanda kurung siku ( [ ] ), tanda petik ("...."), tanda petik tunggal ( '...'), tanda garis miring ( / ), dan tanda penyingkat $\left({ }^{\prime}\right)$. Tidak semua tanda baca tersebut lazim dipakai dalam surat dinas. Oleh karena itu, bahasan tanda baca dalam surat dinas akan dibatasi khusus pada tanda baca yang biasa dipakai dalam surat dinas. Bahasan yang diberikan masih menggunakan model contoh data, uraian kesalahan, dan pembetulannya.

Tanda Titik (.)

Penggunaan tanda titik yang salah sering ditemukan pada bagian-bagian surat, yaitu pada akhir tanggal surat,akhir hal surat, akhir alamat tujuan, penulisan singkatan nomor induk pegawai (NIP), akhir penulisan angka di NIP, dan akhir bagian tembusan surat. Berikut dikemukakan beberapa contoh berdasarkan data yang ada.

5) Kendari, 07 April 2016.

6) Perihal: Penyampaian hasil Seleksi Program Pertukaran Pemuda Antar Negara (PPN).

7) Kepada

Yth. Kepala Dinas Pemuda dan Olahraga atau yang menangani bidang Kepemudaan di Kabupaten/Kota se - Prov. Sultra. Masing - Masing. di -

$\underline{\mathrm{Te}} \mathrm{mp} \mathrm{at}$

8) NIP. 196107201987121001.

9) Tembusan Yth. :

1. Menteri Dalam Negeri, sebagai laporan;

2. Sekretaris Tim Pelaksana Percepatan KSP Kemenko Bidang Perekonomian;

3. Bupati/Walikota Seluruh Indonesia.

10) TP. PKK

Kasus penggunaan tanda titik (.) berdasarkan data di atas, memperlihatkan kurangnya pengetahuam penulis/pembuat 
surat mengenai ketentuan pemakaian tanda titik. Seharusnya, penggunaan tanda titik pada kasus-kasus tersebut tidak dibutuhkan.

Adapun hal lain yang ditemukan berkaitan dengan penggunaan tanda titik adalah seharusnya ada unsur yang menggunakan tanda titik tetapi tidak digunakan, yakni dalam penulisan gelar akademis, penulisan singkatan yang terdiri atas dua huruf. Berikut ini dikemukakan beberapa kasus yang ditemukan.

11) Drs. H. Tasman Taewa, M. Si

12) Muh. Salim, S.Pd, ST., M.Si

13) Up.

14) Cq.

Sebagaimana yang diatur dalam Pedoman Ejaan bahwa penggunaan tanda titik digunakan pada singkatan gelar pada setiap unsur singkatan tersebut. Seharusnya penulisan yang benar adalah M.Si. Begitu juga dengan penggunaan tanda titik dalam singkatan yang terdiri atas dua huruf yang lazim digunakan dalam surat-menyurat, masing-masing diikuti tanda titik. Data 13) dan 14) seharusnya perbaikannya berikut, u.p. dan c.q. Khusus singkatan c.q., sebagaimana yang dijelaskan sebelumnya adalah berasal dari bahasa Latin yang kepanjangannya adalah casu quo, seharusnya penulisannya dimiringkan.

\section{Tanda Titik Dua (:)}

Dalam bahasa surat dinas ditemukan penggunaan tanda titik dua (:) yang masih kurang tepat atau salah penggunaannya. Seharusnya hal ini tidak perlu terjadi jika penulis atau pengirim surat lebih teliti dan lebih menambah pengetahuan mengenai penulisan tanda baca.

Berikut ini dikemukakan beberapa kasus penggunaan tanda titik dua (:) yang tidak sesuai dengaan kaidah yang berlaku.

15) ... di wilayah masing-masing, yang insha Allah dilaksanakan pada :

Hari : Senin

Tanggal : 12 Desember 2016
Jam : 15.00 Wita

Tempat : Masjid Islamic Center Baubau

16) ... tentang Percepatan Perekaman KTP-El maka dengan ini disampaikan :

17) Untuk memenuhi surat Saudara Nomor : 800 / $060 / 2016$ tanggal 07 Mei 2016, ... .

18)

Jl. Pemuda no.181 Kolaka Telp. (0405) 21225 Fax. 21930

Email:dikdasdikmudora@gmail.com

Website : www.dispenda.kolakakab.go.id

Perhatikan penggunaan tanda titik dua (:) pada unsur yang ditebalkan pada kasus di atas.Penggunaan tanda titik dua (:) pada data 15) dan 16) tidak tepat karena bukan merupakan suatu pernyataan lengkap. Jadi, seharusnya tidak menggunakan tanda titik dua.

Yang perlu diperhatikan juga adalah penggunaan tanda titik dua setelah kata yang mendahuluinya tidak diberi spasi atau jarak. Jika model pemeriannya seperti data 15) dan 16), tiap pemerian tidak menggunakan huruf kapital di awal kata. Berikut ini adalah perbaikan dari data 15) dan 16).

1) ... di wilayah masing-masing, yang insyaallah dilaksanakan pada

hari: Senin

tanggal: 12 Desember 2016

pukul : 15.00 Wita

tempat: Masjid Islamic Center Baubau.

2) ... tentang Percepatan Perekaman KTP-el, dengan ini disampaikan

1. seluruh camat dan lurah untuk mengimbau ....;

2. nama-nama setiap warga RT/RW yang belum merekam ....

Untuk data 17) dan 18), penggunaan tanda titik dua juga tidak diperlukan. Adapun nomor surat ditulis tidak menggunakan jarak/spasi. Termasuk penulisan tanggal yang tidak harus dituliskan angka 07, tetapi cukup 7. Jadi, langsung ditulis saja seperti contoh berikut. 
3) Untuk memenuhi surat Saudara nomor 800/060/2016, tanggal 7 Mei 2016, ....

Data 18) merupakan model penulisan kepala surat dari salah satu instansi. Penggunaan tanda titik dua tidak diperlukan di depan kata email dan website. Hal lainnya adalah tidak perlu ditulis menggunakan huruf miring untuk informasi mengenai instansi. Berikut ini adalah perbaikan dari data 18).

4)

Jalan Pemuda, Nomor 181 Kolaka, Telepon

(0405) 21225; Faksimile 21930

Poseldikdasdikmudora@gmail.com,

Laman www.dispenda.kolakakab.go.id

Tanda Koma (,)

Penggunaan tanda koma (,) dalam surat dinas masih banyak yang memperlihatkan ketidaktepatan dalam pemakaian. Dalam Pedoman Ejaan, tanda koma digunakan di antara unsur-unsur dalam suatu pemerincian atau pembilangan. Banyak kalimat yang seharusnya menggunakan tanda koma, tetapi tidak dipakai. Berikut contoh kasus pemerincian dalam kepala surat yang tidak menggunakan tanda koma.

Jl. Pemuda no.181 Kolaka Telp. (0405) 21225 - Fax. 21930

Email:dikdasdikmudora@gmail.com

Website : www.dispenda.kolakakab.go.id

Berikut adalah perbaikan dari kasus tersebut.

Jalan Pemuda, Nomor 181, Kolaka, Telepon (0405)

21225; Faksimile 21930

Posel dikdasdikmudora@gmail.com,

Laman www.dispenda.kolakakab.go.id

Kesalahan umum penggunaan tanda koma (,) yang ditemukan dalam surat dinas adalah tidak dipakai untuk memisahkan anak kalimat yang mendahului induk kalimat. Berikut ini dikemukakan satu contoh kasus.
(19)

Dalam rangka merekonstruksi sejarah kekerabatan antara Buton-Bone melalui Napak Tilas Aru Palakka di Kesultanan Buton tanggal 27 Desember 2016 maka dengan ini disampaikan untuk berpartisipasi mengikuti Karnaval Budaya yang akan dilaksanakan pada:

Hari : Selasa

Tanggal :27 Desember 2017

Berikut ini perbaikan dari kalimat tersebut.

Dalam rangka merekonstruksi sejarah kekerabatan antara Buton-Bone melalui Tapak Tilas Aru Palakka di Kesultanan Buton, kami menyampaikan kepada Bapak/Ibu untuk berpartisipasi mengikuti Karnaval Budaya yang akan dilaksanakan pada hari : Selasa tanggal: 27 Desember 2017

Tanda Hubung (-)

Sesuai dengan namanya, fungsi tandahubung ialah untuk menghubungkan unsur yang satu dengan unsur yang lain. Unsur-unsur tersebut dapat berupa kata, suku kata, awalan, akhiran, huruf, dan angka.Berikut ini dikemukakan beberapa data yang memperlihatkan penggunaan tanda hubung yang bukan pada tempatnya.

20) Nomor : :341/1788

Lampiran : -

Perihal : Data Anggota Satuan Linmas

21) Kepada

Yth. 1. Camat se- Kota Baubau

2. Lurah se- Kota Baubau

di -

Baubau

22)

Jalan Achmad yani No. 67 Kadia, Kendari 93117

TLP.(62-0401) 3192070 - 3192068 FAX. 3191899

23) Hari/Tanggal : Minggu, 19 Februari 2017

Pukul : 09.30 Wita-Selesai

Tempat : Kantor Kecamatan Batu Poaro

Berdasarkan data tersebut, dapat dikemukakan bahwa masih banyak penulis dan konseptor surat yang belum mengetahui penempatan penggunaan tanda hubung. 
Bahkan, seringkali penulis surat tidak dapat membedakan penggunaan tanda hubung (-) dan tanda pisah (--). Tidak jarang ditemukan ada kata ulang yang menggunakan tanda pisah (--).

Pada data 20), penggunaan tanda hubung tersebut dimaksudkan untuk menginformasikan bahwa surat tersebut tidak memiliki lampiran. Kalau seperti itu kasusnya, sebaiknya kata lampiran sebaiknya dihilangkan saja karena surat tersebut tidak memiliki lampiran (sebagaimana yang telah dibahas sebelumnya). Untuk data 21), tanda hubung pada kata $d i$ tidak perlu dipakai.Sementara itu, tanda hubung untuk menghubungkan unsur se dan Kota seharusnya tidak diberi jarak/spasi. Pada data 22), tanda hubung sebaiknya diganti dengan tanda koma (,) karena merupakan perincian.Sementara itu, data 23) seharusnya tidak menggunakan tanda hubung, tetapi tanda pisah (--).

Tanda Pisah (--)

Dalam surat-menyurat, tanda pisah umumnya digunakan di antara dua bilangan, tanggal, atau tempat yang berarti 'sampai dengan' atau 'sampai ke'. Berikut ini dikemukakan data penggunaan tanda pisah yang bukan pada tempatnya.

24) Dalam rangka peringatan Hari Jadi Kota Baubau ke - 475 dan Hari Ulang Tahun Kota baubau Ke-15

25) ..., kami kirimkan nama - nama hasil seleksi Pertukaran Pemuda Antar Negara (PPAN) Tahun 2016. Masing - masing program kegiatan satu (1) Surat Keputusan dengan nominasi lima (5) besar serta Nilai hasil seleksi. (SK, nama -nama peserta terlampir).

Berdasarkan kasus tersebut, dapat dilihat penggunaan tanda pisah yang kurang tepat penggunaannya. Dalam data 24), seharusnya penulisan yang menggabungkan unsur huruf dan angka menggunakan tanda hubung. Penulisan kata ulang pada data 25) seharusnya menggunakan tanda hubung.
Masih banyak penulisan bentuk ulang dalam data surat dinas menggunakan tanda pisah. Tanda pisah (-) memang mirip dengan tanda hubung (-), hanya tanda pisah lebih panjang. Pembetulan dari kalimat yang salah di atas sebagai berikut.

Dalam rangka peringatan Hari Jadi Kota Baubau ke-475 dan Hari Ulang Tahun Kota Baubau ke-15 ....

..., kami kirimkan nama-nama hasil seleksi Pertukaran Pemuda Antarnegara (PPAN) Tahun 2016. Setiap program kegiatan satu surat keputusan dengan nomine lima besar serta nilai hasil seleksi (SK dan nama-nama peserta terlampir).

Tanda Garis Bawah (_)

Tanda garis bawah sebenarnya tidak dibahas dalam Pedoman Ejaan Bahasa Indonesia. Tanda garis bawah ini tergantikan posisinya oleh penulisan huruf miring dan fungsinya sama dengan penulisan huruf miring. Tanda garis bawah diurai pada kajian ini karena dalam penulisan surat dinas masih banyak yang menggunakannya. Misalnya, kasus seperti ini sangat sering ditemukan dalam penulisan hal surat, alamat tujuan, nama pejabat penanda tangan surat, dan kata tembusan surat. Kasus tersebut dapat dilihat dalam contoh berikut.

26) Perihal: Pemberian Izin Pelaksanaan

27) $\frac{\text { Test Intelegensi Siswa }}{\text { Kepada }}$

Yth. 1. Camat se- Kota Baubau

2. Lurah se- Kota Baubau di -

$\underline{\text { Baubau }}$

\section{a.n. WALIKOTA BAUBAU} Sekretaris Daerah,

Drs. MUHAMAD DJUDUL, M.Si. Pembina Utama Madya NIP. 196309011991011009

29) Tembusan : Disampaikan kepada Yth.

1. Bupati Kolaka (sebagai laporan) di Kolaka;

2. Ketua DPRD Kab. Kolaka di Kolaka; 
3. Inspektorat Kab. Koalak di Kolaka;

4. Kepala BAPPEDA Kab. Kolaka di Kolaka;

5. Arsip;

Perhatikan data-data di atas. Dalam surat dinas seringkali didapati penggunaan garis bawah, bahkan ditebalkan, dengan alasan untuk penegasan. Alasan tersebut kurang berterima. Pada kasus-kasus tersebut tidak ada aturan mengenai penggunaan garis bawah dalam Pedoman Ejaan Bahasa Indonesia. Penulisan hal surat tidak perlu menggunakan garis bawah, apalagi ditebalkan. Yang umum juga juga didapati adalah penggunaan garis bawah pada pejabat penanda tangan surat. Termasuk juga penulisan nama kota atau daerah di tujuan surat dan tembusan surat.

Tanda Kurung (( ))

Tanda baca lain yang sering digunakan dalam surat dinas adalah tanda kurung. Namun, penggunaan tanda kurung banyak yang tidak sesuai dengan aturan yang ada. Tanda kurung umumnya digunakan untuk mengapit tulisan dari angka Arab yang banyak digunakan dalam lampiran surat.

30) Lampiran: 5 (lima) lbr

31) Lampiran: 1 (satu) berkas

Berdasarkan aturan yang ada bahwa penulisan angka yang unsurnya tidak lebih dari dua kata ditulis dengan huruf. Hal lain yang perlu dikemukakan adalah dalam surat dinas sebaiknya dihindari penulisan singkatan yang tidak lazim dan tidak perlu, misalnya dalam data 30 ), penulisan 'lbr'.

\section{Tanda Titik Koma (;)}

Penggunaan tanda titik koma banyak ditemukan dalam penulisan tembusan surat yang lebih dari satu. Tanda titik dua pada tembusan surat tidak dibutuhkan. Berikut dapat dilihat salah satu contohnya.

32) Tembusan : Disampaikan kepada Yth.: 1. Bupati Kolaka (sebagai laporan) di Kolaka;

2. Ketua DPRD Kab. Kolaka di Kolaka;
3. Inspektorat Kab. Koalak di Kolaka;

4. Kepala BAPPEDA Kab. Kolaka di Kolaka; 5. Arsip;

Penulisan Unsur Serapan dan Penggunaan Bahasa Asing

Dalam penelitian ini, yang berkaitan dengan penulisan unsur serapan dan penggunaan bahasa asing umumnya yang digunakan adalah unsur serapan dari bahasa Inggris. Berikut ini dikemukakan beberapa unsur serapan yang kurang tepat penulisannya dalam bahasa Indonesia yang ditemukan dalam data surat dinas.

Tabel 10

Kesalahan Penulisan Unsur Serapan

\begin{tabular}{|c|c|c|}
\hline No. & $\begin{array}{c}\text { Penulisan Unsur } \\
\text { Serapan yang Salah }\end{array}$ & Perbaikan \\
\hline 1. & test intelegensi siswa & $\begin{array}{l}\text { tes inteligensi } \\
\text { siswa }\end{array}$ \\
\hline 2. & kreatifitas & kreativitas \\
\hline 3. & club sepak bola & klub sepak bola \\
\hline 4. & turnamen volley pantai & $\begin{array}{l}\text { turnamen voli } \\
\text { pantai }\end{array}$ \\
\hline 5. & $\begin{array}{l}\text { Crash } \\
\text { Campak }\end{array}$ & $\begin{array}{l}\text { Program Cepat } \\
\text { Campak }\end{array}$ \\
\hline 6. & Lumpsum & lumsum \\
\hline 7. & $\begin{array}{l}\text { Sosialisasi Program } \\
\text { Lumbung Pangan Desa } \\
\text { dan Onfarm }\end{array}$ & $\begin{array}{l}\text { Sosialisasi } \\
\text { Program Lumbung } \\
\text { Pangan Desa dan } \\
\text { Pertanian }\end{array}$ \\
\hline 8. & Devile & defile \\
\hline 9. & asset & aset \\
\hline 10. & examplar & eksemplar \\
\hline
\end{tabular}

Data di atas menunjukkan bahwa penulisan unsur serapan masih ada yang menuliskan dalam bahasa asingnya, bahasa Inggris. Penulisan dan penggunaan unsur serapan ini digabung dengan kosakata bahasa Indonesia. Secara teknis, penulisan unsur asing yang sudah diserap relatif mudah untuk dituliskan dalam bahasa Indonesia. Ada beberapa data, seperti data 5 (crash program) dan data 7 (onfarm) yang harus diterjemahkan ke dalam bahasa Indonesia. Kemungkinan yang menulis kata kurang memahami arti dari kosakata tersebut 
yang pada akhirnya hanya mencontoh kata yang sudah ada.

Penulisan unsur serapan seiring sejalan dengan penggunaan istilah asing. Oleh karena surat dinas ditulis dalam bahasa Indonesia, penggunaan istilah asing bercampur baur atau menyisip di antara kosakata bahasa Indonesia. Bahkan, penggunaan istilah asing tersebut tidak dimiringkan sesuai dengan aturan dalam tata cara penulisan ejaan bahasa Indonesia.

Tabel 11

Penggunaan Istilah Asing

\begin{tabular}{clc}
\hline No. & \multicolumn{1}{c}{$\begin{array}{c}\text { Penggunaan } \\
\text { Bahasa Asing }\end{array}$} & Arti \\
\hline 1. & mangrove & bakau \\
\hline 2. & soft copy & kopi lunak \\
\hline 3. & hard copy & kopi cetak \\
\hline 4. & Baubau Expo & Pameran Baubau \\
\hline 5. & coaching clinic & $\begin{array}{c}\text { pelatihan } \\
\text { singkat/klinik } \\
\text { pelatihan }\end{array}$ \\
& & posel \\
\hline 6. & email & faksimile \\
\hline 7. & faximile & laman \\
\hline 8. & website & narahubung \\
\hline 9. & kontak person & narahubung \\
\hline 10. & contack person & narahubung \\
\hline 11. & contac person & narahubung \\
\hline 12. & contact person &
\end{tabular}

Data di atas menunjukkan bahwa penggunaan istilah asing umumnya diambil dari bahasa Inggris. Terjemahan dari istilahistilah bahasa Inggris relatif mudah untuk diterjemahkan atau dicari padanannya. Jadi, bergantung pada luasnya pengetahuan bahasa si penulis surat.

Khusus data 5 (coaching clinic) yang penerjemahannya membutuhkan pengetahuan bahasa Inggris yang lebih dalam. Terjemahan coaching clinic yang banyak ditemukan di Google adalah klinik pelatihan atau pelatihan singkat. Dalam bahasa Inggris, arti clinic yang diambil adalah sebagai berikut:

clinic: a lesson or series of lessons taught to persons not expert in some activity, in which the errors of the students are pointed out, and remedial actions are suggested.

Jadi, bukan klinik dalam arti balai pengobatan khusus.

Khusus untuk istilah contact person, berdasarkan data di atas terdiri atas empat jenis penulisan yang berbeda dengan makna yang sama. Istilah contact person dapat diterjemahkan menjadi 'narahubung', artinya orang yang dapat dihubungi. Penggunaan narahubung ini beranalogi ke bentuk narasumber dan narapidana.Yang menjadi masalah adalah penulisan istilah asing yang penulisannya tidak tepat. Jadi, lebih baik menghindari penggunaan istilah asing kalau tidak mengetahui cara penulisannya. Kalaupun ingin menuliskannya, sebaiknya ditulis dengan huruf miring.

\section{Penggunaan Diksi dalam Surat Dinas}

Diksi adalah pilihan kata yang dipergunakan untuk menyusun suatu kalimat.Pemakaian diksi dalam surat resmi biasanya meliputi ketepatan, keumuman, kehematan, kebakuan, dan kehalusan makna. Masalah penggunaan diksi dalam surat dinas dijelaskan secara umum. Berikut ini dikemukakan beberapa data dalam surat dinas yang penggunaan diksinya kurang tepat. Diksi yang kurang tepat penggunaannya diberi huruf tebal.

33) Dalam rangka kunjungan kerja Direksi Perum BULOG beserta rombongan dari Jakarta, di mana salah satu agendanya adalah .....

34) Demikian undangan ini, atas perhatian dan perkenan serta kerjasamanya diucapkan terima kasih.

35) Masing - masing program kegiatan satu (1) Surat Keputusan dengan nominasilima (5) besar serta Nilai hasil seleksi. (SK , nama nama peserta terlampir).

36) Dengan hormat kami laporkan kepada Bapak Gubernur bahwa ....

37) Menunjuk Surat Sekretaris daerah Prov. Sultra .... 
38) Untuk memenuhi surat Saudara Nomor : 800 / 060 /2016 tanggal 07 Mei 2016 perihal Permohonan Tempat Pelaksanaan Praktek Kerja Industri (Prakerin), kami setuju dan siap menerima dan membimbing Siswa Prakerin.

39) Penetapan pemenang berdasarkan hasil seleksi di kabupaten/kota segera menyampaikan ke Dinas ......

40) Apabila karena sesuatu hal yang tidak dapat dihindari maka jadwal akan disesuaikan kemudian.

41)... dengan ketentuan hal-hal yang sifatnya prinsipil dilaporkan Kepada Kepala Dinas Pemuda dan Olahraga Provinsi Sulawesi Tenggara.

Ketepatan penggunaan diksi sangat dipengaruhi oleh kemampuan bahasa yang terkait dengan kemampuan mengetahui, memahami, menguasai, dan menggunakan kosakata secara aktif sehingga pengguna bahasa dapat mengungkapkan gagasan secara tepat dalam rangka menjalin komunikasi yang efektif. Beberapa data di atas dapat diurai satu per satu dalam upaya mencari kata atau kosakata yang sesuai dan cocok. Surat dinas sebagai sarana komunikasi yang resmi atau formal harusnya menggunakan bahasa baku atau bahasa yang baik dan benar, termasuk diksinya yang harus tepat.

Pada data 33), penggunaan kata dimana merupakan kata yang kurang tepat untuk mengisi posisi dalam rangkaian kalimat tersebut. Kata dimana umumnya digunakan dalam kalimat pertanyaan, sementara kalimat dalam data tersebut tidak ada unsur pertanyaan. Penggunaan kata dimana dipengaruhi oleh struktur dalam bahasa Inggris yang lazim menggunakan kata tanya dalam melengkapi keterangan tambahan dalam sebuah kalimat, seperti kata in which, where, who, dan sebagainya. Jadi, kata yang lebih cocok untuk mengganti kata tersebut adalah kata yang. Berikut ini adalah perbaikan kalimat tersebut.
Dalam rangka kunjungan kerja Direksi Perum BULOG beserta rombongan dari Jakarta yang salah satu agendanya adalah .....

Data 34) merupakan kalimat penutup yang sangat lazim dijumpai dalam surat dinas. Kalimat penutup dalam data tersebut terlalu panjang sehingga tidak lugas. Banyak unsur yang seharusnya tidak perlu ada yang tidak mengurangi rasa hormat pengirim/penulis surat kepada penerima surat. Klausa demikian kami sampaikan tidak perlu hadir dalam kalimat penutup karena penerima surat setelah membaca surat tersebut pasti pesan sudah tersampaikan. Biasanya klausa ini dihadirkan oleh penulis hanya untuk berbasa-basi supaya terkesan lebih menghormati. Masalah lain dalam diksi di kalimat penutup surat dinas adalah penggunaan kata perhatian, perkenan, kerja sama, kesediaan, bantuan, dan sebagainya, harus tepat. Yang lazim digunakan dalam kalimat penutup hanya dua kata, misalnya perhatian dan kerja sama, kerja sama dan kesediaan, bergantung pada hal surat. Jika isinya adalah undangan, yang lebih sesuai adalah perhatian dan kesediaan atau kerja sama dan kesediaan. Masalah yang sangat lazim ditemui juga adalah penggunaan unsur -nya. Hampir semua surat dinas, bahkan surat nonresmi pun, tidak lepas dari penggunaan unsur ini pada kalimat penutup. Setiap kali penyuluhan bahasa surat, masalah ini selalu dibahas berulang-ulang, tetapi tetap masih juga dipakai. Unsur $-n y a$ adalah bentuk terikat (pronomina benda yang menyatakan milik) digunakan untuk kata ganti kepunyaan orang ketiga. Dalam surat-menyurat, yang terlibat dalam komunikasi adalah hanya si penulis (sebagai orang pertama) dan si penerima surat (sebagai orang kedua). Tidak ada orang ketiga dalam surat-menyurat tersebut sehingga penggunaan unsur - nya tidak tepat dalam kasus tersebut. Jadi, unsur yang tepat untuk menggantikan -nya adalah langsung 
menyebut kata sapaan yang sesuai bagi si penerima surat (biasanya berdasarkan jenis kelamin), misalnya, Bapak, Ibu, atau Saudara. Karena ini adalah sapaan, penggunaan huruf kapital di awal kata harus digunakan. Jika, tidak diketahui jenis kelamin kepala dinas/kantor, ditulis sekaligus dua-dua yang dipisahkan oleh garis miring, seperti Bapak/Ibu. Penggunaan kata sapaan Bapak/Ibu atau Saudara sangat ditentukan oleh posisi pengirim surat dan kepada siapa surat tersebut ditujukan. Kalau untuk staf, seharusnya digunakan sapaan Saudara. Kalau surat ditujukan kepada orang yang posisinya sederajat atau yang lebih tinggi dapat digunakan sapaan Bapak/Ibu. Perbaikan data tersebut dapat dilihat berikut ini.

Atas perhatian dan kesediaan Bapak diucapkan terima kasih.

Atas perhatian dan kerja sama Bapak, kami ucapkan terima kasih.

Dalam data 35), penggunaan kata nominasi tidak tepat dalam kalimat tersebut. Dalam KBBI, definisi nominasi adalah 'pengusulan atau pengangkatan sebagai calon; pencalonan'. Kata nominasi adalah kata serapan dari bahasa asing yang penggunaannya lazim dipertukarkan dengan kata nomine dan nominator yang juga merupakan unsur serapan.Arti dari nomine adalah 'orang yang dicalonkan (diunggulkan)', sementara nominator adalah 'orang yang mencalonkan'.

Konteks kalimat dalam surat tersebut adalah proses seleksi sudah dilaksanakan, terpilihlah lima orang yang akan lanjut ke tahap berikutnya. Proses pencalonan atau nominasi sudah berlangsung dan terpilih lima calon yang masuk dalam lima besar yang diunggulkan untuk jadi juara. Jadi, yang dimaksud dalam kalimat tersebut adalah orang yang diunggulkan atau nomine.
Setiap program kegiatan satu surat keputusan dengan nomine lima besar dan nilai hasil seleksi (SK dan nama-nama peserta terlampir).

Berikutnya adalah data 36) yang berkaitan dengan penggunaan kata sapaan. Kata sapaan berkaitan dengan kata untuk menegur sapa orang yang diajak berbicara (orang kedua) atau menggantikan nama orang ketiga.Di Indonesia, penggunaan kata sapaan sangat terikat pada adat kesantunan, serta situasi dan kondisi percakapan. Karena itu, kaidah kebahasaan sering terabaikan karena ada pertimbangan adat kebiasaan yang berlaku di Indonesia.

Dalam surat dinas sapaan yang biasa digunakan adalah Bapak, Ibu, Saudara, serta nama diri. Dalam aturan kebahasaan, bahwa penulisan nama sapaan tidak perlu diikuti nama jabatandan dalam menulis kata sapaan harus digunakan di depan nama orang. Jika ingin menuliskan jabatan saja, nama sapaan tidak perlu dituliskan.

Dalam kasus data 36), penulisan sapaan mengikuti jabatan yang secara aturan tidak tepat. Jadi, seolah-olah surat tersebut ditujukan kepada orang yang bernama Gubernur. Kasus seperti ini banyak ditemukan dalam surat-surat dinas. Salah satu yang biasa dipakai adalah Bapak Sekretaris Daerah. Padahal, tanpa penggunaan sapaan Bapak pun surat yang ditujukan kepada salah seorang pejabat, misalnya, tidak akan mengurangi kadar kesopanan surat dinas. Dalam konteks surat dinas tersebut yang dimaksud adalah Gubernur Sulawesi Tenggara yang dapat digantikan dengan sapaan Bapak. Berikut adalah perbaikan dari kalimat tersebut. bahwa ...

Dengan hormat kami laporkan kepada Bapak

Berikutnya adalah data 37) dan 38). Data tersebut berkaitan dengan diksi dalam pendahuluan surat. Dalam penulisan surat dinas kita bisa memilih macam-macam model atau varian pembukaan bergantung 
pada surat apa yang akan dibuat. Variasivariasi pembuka surat tersebut dapat berupa surat pemberitahuan, permintaan, ataupun pertanyaan; surat balasan; surat untuk menunjuk pada dasar surat; dan surat untuk menyatakan sebuah tujuan.

Dalam konteks data 37), surat tersebut merupakan surat untuk menunjuk pada dasar surat. Secara logika, penggunaan kata menunjuk pada data tersebut tidak sesuai karena seolah-olah surat tersebut hanya ditunjuk oleh pengirim surat padahal maksudnya adalah merujuk atau berdasarkan surat yang dikirim sebelumnya. Kata menunjuk dapat diganti dengan kata merujuk atau berdasarkan. Berikut adalah perbaikan dari kalimat tersebut.

Merujuk surat Sekretaris Daerah Prov. Sultra ....

Berdasarkan surat Sekretaris Daerah Prov. Sultra

Dalam kalimat pendahuluan dalam surat di data 38), yang merupakan surat balasan, penggunaan kata memenuhi kurang lazim didengar. Kata tersebut dapat diganti dengan kata membalas atau berkenaan dengan. Selain itu, penggunaan kata penghubung dan juga sangat berlebihan. Termasuk juga di dalamnya penggunaan kata setuju yang berlebihan karena setelahnya sudah ada kata siap. Dalam konteks surat tersebut, kedua kata itu memiliki nuansa makna yang sama. Jadi, cukup digunakan salah satu dari kedua kata tersebut. Berikut adalah perbaikan dari kalimat tersebut.

Membalas surat Saudara bernomor 800/060/2016, 7 Mei 2016, perihal permohonan tempat pelaksanaan Praktek Kerja Industri (Prakerin), kami setuju menerima dan membimbing siswa Prakerin tersebut.

Penjelasan berikutnya adalah data 39), berkaitan dengan logika berbahasa. Secara logika, penetapan pemenang tidak mungkin menyampaikan sesuatu kepada kepala dinas. Seharusnya yang ingin disampaikan adalah penetapan pemenang.Berikut ini perbaikan dari kalimat tersebut.

Penetapan pemenang berdasarkan hasil seleksi di kabupaten/kota segera disampaikan ke Dinas ....

Masalah lain yang berkaitan dengan diksi dapat dilihat pada data 40). Data tersebut memperlihatkan penggunaan dua kata penghubung dalam satu kalimat. Masalah ini sangat lazim ditemukan dalam berbagai tulisan, bukan hanya surat. Ada anggapan yang salah kaprah bahwa kata jika selalu berpasangan dengan kata maka. Ketika ada kata jika, kata maka harus muncul juga. Ini kekeliruan yang diajarkan kepada kita sejak kecil. Sebenarnya, kedua kata penghubung tersebut memiliki makna yang berbeda.Kata jika adalah kata penghubung untuk menandai syarat (janji), Kata jika bersinonim dengan kata apabila. Kata maka adalah kata penghubung untuk menyatakan hubungan akibat. Berikut ini perbaikan dari kalimat tersebut.

Apabila ada sesuatu hal yang tidak dapat dihindari, jadwal akan disesuaikan kemudian.

Berikutnya adalah penggunaan kata serapan yang tidak sesuai dengan penulisan dalam bahasa Indonesia, seperti pada data 41). Secara lisan kata tersebut biasa kita lafalkan dengan prinsipil. Namun, dalam penulisan atau ejaan, yang benar adalah prinsipiel.

$$
\begin{aligned}
& \text {.. dengan ketentuan hal-hal yang sifatnya } \\
& \text { prinsipiel dilaporkan kepada Kepala Dinas } \\
& \text { Pemuda dan Olahraga Provinsi Sulawesi } \\
& \text { Tenggara. }
\end{aligned}
$$

\section{PENUTUP}

Berdasarkan analisis data dan pembahasan dapat dikemukakan simpulan sebagai berikut. Penggunaan bahasa dalam surat dinas di instansi pemerintah daerah di Sulawesi Tenggara banyak memperlihatkan 
ketidakseragaman dalam instansi yang sama. Bukan hanya penggunaan bahasanya yang bervariasi, melainkan juga penggunaan format surat, misalnya penggunaan logo yang tidak sama ukurannya, penggunaan besar dan jenis huruf. Masih banyak juga yang menggunakan istilah asing seperti fax, email, dan website.

Selain itu, juga ditemukan pencantuman nama tempat pembuatan sebelum penulisan tanggal. Penulisan lampiran umumnya disingkat menjadi Lamp. Penyingkatan seperti itu tidak dianjurkan dalam penulisan surat dinas, seharusnya ditulis lengkap. Banyak juga yang menuliskan lampiran tetapi tidak ada berkas yang dilampirkan. Kesalahan umum yang terjadi adalah penulisan angka lampiran dan harus diawali dengan huruf kapital. Berkaitan dengan penulisan hal surat, ada beberapa yang menuliskannya terlalu panjang, diakhiri dengan tanda titik, dan diberi garis bawah. Untuk penulisan alamat tujuan surat, kesalahan umum yang ditemukan adalah penggunaan kata kepada, $d i$, penggunnaan tanda titik di akhir alamat, dan penggunaan garis bawah pada daerah tujuan.

Dalam paragraf penutup, penggunaan kata ganti milik orang ketiga -nya masih umum digunakan. Pada bagian penutup, masih banyak surat dinas bertuliskan huruf kapital nama pejabat dan nama jabatan, penulisan NIP masih menggunakan tanda titik dan ada kelompok angka yang diberi spasi, nama pejabat masih diberi garis bawah, penulisan gelar yang kurang tepat, dan penulisan tembusan surat yang kurang tepat.

Penggunaan ejaan dan diksi ditemukan bahwa ketidaktepatan penggunaan huruf kapital ban yak ditemui pada penulisan halsurat. Umumnya, data yang ada menulis hal dengan menggunakan huruf kapital di tiap awal kata. Nama jabatan dan nama pejabat umumnya ditulis dengan huruf kapital. Berdasarkan aturan yang ada, seharusnya pemakaian huruf kapital hanya di tiap awal kata atau dipakai sebagai huruf pertama unsur nama orang. Sebagaimana pemakaian huruf kapital, pemakaian huruf tebal seharusnya tidak digunakan pada hal surat, penulisan nama pejabat, dan penulisan nama jabatan. Bahkan, ditambah lagi dengan penggunaan garis bawah.Kesalahan penulisan kata dasar umumnya terjadi pada kata serapan. Penulisan antara imbuhan $d i$ dan kata depan $d i$ masih ada yang belum dapat membedakan pemakaiannya. Selain itu, sebagian besar masih ada yang menganggap bahwa tanda hubung (-) dan tanda pisah (--) adalah dua hal yang sama. Dalam kaitannya dengan pemakaian tanda baca, kesalahan umum yang terjadi adalah ketidaktepatan penggunaan tanda titik (.), titik dua (:), tanda koma (,), tanda hubung, tanda garis bawah, tanda kurung, dan tanda titik koma (;). Sementara penggunaan unsur serapan masih banyak yang tidak tepat penulisannya karena masih menggunakana ejaan dalam bahasa asing dengan susunan kata/kalimat dalam bahasa Indonesia.

Berikut ini pula dikemukakan beberapa saran yang dapat dijadikan masukan. Penelitian seperti ini masih sangat penting untuk dilakukan karena dapat menjadi masukan dan perbaikan bagi instansi pemerintah dalam melakukan penulisan naskah-naskah dinas sebab naskah dinas memiliki aturan tersendiri yang diatur dengan peraturan-peraturan resmi, termasuk penggunaan bahasa resmi. Beberapa kesalahan mendasar dalam penulisan surat berdasarkan penelitian ini dapat menjadi masukan bagi konseptor surat dinas. Perlu ada penunjukan konseptor surat yang paten di tiap instansi pemerintah daerah agar surat dinas yang dihasilkan seragam, khususnya dalam format. Selain itu, penunjukan seorang konseptor surat dapat mempermudah dan memfokuskan pembahasan antara penyuluh bahasa dan konseptor surat. 
Instansi pemerintah daerah perlu melibatkan ahli-ahli bahasa dalam melakukan pembuatan tata naskah dinas dan perencanaan produk-produk hukum daerah untuk menghindari terjadinya kesalahan penulisan dalam hal-hal tersebut.

\section{DAFTAR PUSTAKA}

Angi, M. (2009). Analisis Kesalahan Bahasa Surat pada Kantor Badan Perencanaan Pembangunan Daerah (BAPPEDA) Kabupaten Jeneponto.

Arifin, E. Z. (1989). Penggunaan Bahasa Indonesia dalam Surat Dinas. PT Mediyatama Sarana Perkasa.

Bety, N. (2009). Kesalahan Penggunaan Ejaan yang Disempurnakan dalam Surat Dinas Bappeda Provinsi Kalimantan Timur. (Beberapa Permasalahan Pemakaian Bahasa Indonesia) (Pertama). Pusat Bahasa, Departemen Pendidikan dan Kebudayaan.

Pedoman Tata Naskah Dinas Instansi Pemerintah, Pub. L. No. 80, (2012).

Bratawidjaja, T. W. (1988). Surat Bisnis Modern. PT Pustaka Binaman Pressindo.

Hastuti, S. (1985). Permasalahan dalam Bahasa Indonesia (Kedua). PT Intan.

Pedoman Umum Ejaan Bahasa Indonesia, Pub. L. No. 50, (2015).

Kridalaksana, H. 2008. Kamus Linguistik. PT Gramedia Pustaka Utama.

M.R., Darmawati. (2019). "Ketidakefektifan Kalimat pada Surat Dinas Pemerintah: Studi Kasus Kabupaten Gorontalo". Telaga Bahasa, 7 (Desember), 241-260.

Nadia, F. dan S. (2018). Surat Dinas: Teori dan Praktik. Pustaka Pelajar.

Nataliasari, W. D. (2014). Analisis Kesalahan Ejaan pada Surat Dinas di Balai Desa Butuh Krajan, Kecamatan Tengaran, Kabupaten Semarang.
Universitas Muhammadiyah Surakarta. Purwandari, Heni Setya, Budhi Setiawan, K. S. (2014). "Analisis Kesalahan Berbahasa Indonesia pada Surat Dinas Kantor Kepala Desa Jladri." Basastra, 1 (April).

Rasyid, A. (2018). "Keberterimaan Bentuk Pengindonesiaan Kata dan Ungkapan Asing di Kalangan Pejabat SKPD SeKabupaten Gorontalo." Telaga Bahasa, 6(Juni), 387--404.

Ratna, N. K. (2013). Teori, Metode, dan Teknik Penelitian Sastra. Pustaka Pelajar.

Ruru, J. H. (1996). Analisis Kesalahan dalam Wacana. Makassar: Universitas Hasanuddin.

Soytaningrum, A. T. (2008). Korespondensi Bahasa Indonesia: Dasar, Teori, dan Aplikasi. Amara Books.

Sudaryanto. (2015). Metode dan Aneka Teknik Analisis Bahasa. Sanata Dharma University Press.

Tarigan, H. G. (1990). Pengajaran Analisis Kesalahan Berbahasa. Angkasa. 
